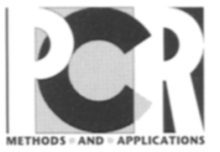

\title{
A Simplified Procedure for Developing Multiplex PCRs
}

\author{
Anthony P. Shuber, ${ }^{1}$ Valerie J. Grondin, and Katherine W. Klinger
}

Department of Technology Development, Integrated Genetics, Inc., Framingham Massachusetts 01701

\begin{abstract}
We have developed a simplified method for multiplex PCR based on the use of chimeric primers. Each primer contains a $3^{\prime}$ region complementary to sequence-specific recognition sites and a 5 ' region made up of an unrelated 20-nucleotide sequence. Identical reaction conditions, cycling times, and annealing temperatures have been established for any PCR primer pair comprising the chimeric motif. Under these conditions, efficient multiplex amplification is achieved easily and reproducibly by simple adjustment of the individual primer concentrations. No additional modification of either the reaction components or annealing temperatures is required. The use of tagged primers provides a method for primer design that eliminates the multiple optimization steps involved in developing multiplex PCR.
\end{abstract}

$\mathbf{W}$ ith the rapid advances in mammalian molecular genetics, an ever increasing number of disease genes have been identified. Accordingly, PCR has gained widespread use for the diagnosis of inherited disorders and the susceptibility to disease. Typically, the region of interest is amplified from either genomic DNA or its cognate cDNA. Mutations or polymorphisms are then identified by techniques such as DNA sequencing, ${ }^{(1,2)}$ hybridization with allele-specific oligonucleotides, ${ }^{(3)}$ oligonucleotide ligation, ${ }^{(4)}$ or single-strand conformational polymorphism (SSCP) analysis. ${ }^{(5)}$ PCR can further be used for the rapid identification of deletions. ${ }^{(6)}$

For the analysis of small genes and transcripts, amplification of a single defined region of DNA may be sufficient. However, when analyzing large genes and transcripts, multiple PCRs may be required to identify critical base changes or deletions. Chamberlain et. al. first demonstrated the use of multiplex PCR for the simultaneous analysis of multiple loci in the human dystrophin gene. ${ }^{(6)}$ Since then, multiplex PCR has been established as a general technique.

However, in general, a number of considerations and optimization steps are involved in developing a robust and efficient multiplex PCR. ${ }^{(7)}$ For example, multiplexing is frequently complicated by artifacts such as the amplification of spurious products resulting from annealing of the primers to nonspecific sequences. Typically, primers should be designed so that their predicted melting temperatures $\left(T_{m}\right)$ are similar to those of the other primers used in the multiplex reaction. Although the annealing tem- peratures and primer concentrations may be calculated to some degree, conditions generally must be defined empirically in multiplex reactions. In addition, as primer sets are added to the multiplex PCR, reaction components (e.g., $\mathrm{Mg}^{2+}$, dNTP, polymerase) and cycling conditions (e.g., annealing temperature, extension time, hot start) must also be adjusted. ${ }^{(7)}$ Therefore, complete optimization of the reaction conditions for multiplex PCR can become labor intensive and time consuming. Because different multiplex PCRs may each have unique reaction conditions, development of new diagnostic tests can become very costly.

The PCR method described in this paper greatly simplifies the establishment of the conditions for multiplex PCR. Our method relies on the use of "chimeric" sequence-specific primers. The chimeric primers are complementary to the recognition sequence of the template DNA and are "tagged" on the 5 ' end with an unrelated 20-nucleotide sequence (universal primer sequence). Our results suggest that the PCR conditions that have been established for the universal primer sequence can be applied directly to multiplex PCRs using chimeric primers. As the same reaction conditions are used for all primer pairs, we have minimized the number of optimization steps that are typically required for the development of multiplex PCRs.

\section{MATERIALS AND METHODS}

\section{Genomic DNA samples}

Whole blood samples were collected in 
TABLE 1 Sequences of Amplicon-specific Primers

\begin{tabular}{|c|c|c|c|c|c|}
\hline \multicolumn{3}{|c|}{ Cystic Fibrosis Transmembrane Regulator (CFTR) 15-plex } & \multicolumn{3}{|c|}{ Gauchers (GCR) and Sickle Cell Anemia (SCA) 4-plex } \\
\hline Primer Sequences & Exon & Size (bp) & GCR Primer Sequences & Exon & Size (bp) \\
\hline $\begin{array}{l}\text { AGG CTT CTC AGT GAT CTG TTG } \\
\text { GAA TCA TTC AGT GGG TAT AAG CAG }\end{array}$ & Int 19 & $\sim 440$ & $\begin{array}{l}\text { GGG TGG GAG GGT GGA GGC TAA TGG } \\
\text { CCA GAA GGT AGA AAG GTG AG }\end{array}$ & 6 & 401 \\
\hline $\begin{array}{l}\text { GCC CGA CAA ATA ACC AAG TGA } \\
\text { AGT CTA ACA AAG CAA GCA GTG }\end{array}$ & 19 & 410 & $\begin{array}{l}\text { GAA TGT CCC AAG CCT TTG A } \\
\text { AAG CTG AAG CAA GAG AAT CG }\end{array}$ & 2 & 358 \\
\hline $\begin{array}{l}\text { TGA TGG TAA GTA CAT GGG TG } \\
\text { CAA AAG TAC CTG TTG CTC CA }\end{array}$ & 21 & 381 & $\begin{array}{l}\text { TGC AAC TAC TGA GGC ACT T } \\
\text { TAC AAT GAT GGG ACT GTC G }\end{array}$ & 9 & 319 \\
\hline CTT CTA ATG GTG ATG ACA GCC T & 9 & 335 & SCA Primer Sequences & & \\
\hline CCA CTG AAA ATA ATA TGA GGA AAT & & & $\begin{array}{l}\text { САT TTG CTT CTG ACA CAA CTG } \\
\text { CCA ACT TCA TCC ACG TTC ACC }\end{array}$ & & 124 \\
\hline $\begin{array}{l}\text { AGG TAG CAG CTA TTT TTA TGG } \\
\text { TAA GGG AGT CTT TTG CAC AA }\end{array}$ & 13 & 295 & $\begin{array}{l}\text { GCR and Tay-Sachs (TS) 3-plex } \\
\text { GCR }\end{array}$ & & \\
\hline $\begin{array}{l}\text { TGT AGG AAG TCA CCA AAG } \\
\text { CGA TAC AGA ATA TAT GTG CC }\end{array}$ & 4 & 267 & $\begin{array}{l}\text { CCT TGC CCT GAA CCC CGA A } \\
\text { CTG ACT CTG TCC CTT TAA TGC CCA }\end{array}$ & $9,10,11$ & 871 \\
\hline GGA GTC CAA TIT TCA CTC ATC TTG & $17 \mathrm{~b}$ & 245 & TS Primer Sequences & & \\
\hline AGT TAA TGA GTT CAT AGT ACC TGT T & & & $\begin{array}{l}\text { GTG TGG CGA GAG GAT ATT CCA } \\
\text { TGG CTA GAT GGG ATT GGG TCT }\end{array}$ & $11,12^{* * *}$ & 530 \\
\hline $\begin{array}{l}\text { AGA TAC TTC AAT AGC TCA GCC } \\
\text { GGT ACA TTA CCT GTA TTT TGT TT }\end{array}$ & 7 & 220 & $\begin{array}{l}\text { GGG TCC TAC AAC CCT GTC ACC CAC } \\
\text { AAG CTT CAC TCT GAG CAT AAC AAG }\end{array}$ & $7^{* *}$ & 190 \\
\hline $\begin{array}{l}\text { CAG ATT GAG CAT ACT AAA AGT G } \\
\text { TAC ATG AAT GAC ATT TAC AGC A }\end{array}$ & 11 & 200 & B-thalassemia Primer Sequences & & \\
\hline $\begin{array}{l}\text { GAG CCT TCA GAG GGT AAA AT } \\
\text { TCA CAT AGT TTC TTA CCT CT }\end{array}$ & 10 & 175 & $\begin{array}{l}\text { GCT GTC ATC ACT TAG ACC TC } \\
\text { GCA AGA AAG CGA GCT TAG TG }\end{array}$ & $1,2,3$ & 1612 \\
\hline & & & WT-1 Primer Sequences & Name & Size (bp) \\
\hline AAG AAC TGG ATC AGG GAA GA & 20 & 155 & CTG AGT GAA TGG AGC GGC & $\mathrm{B}^{*}$ & 204 \\
\hline TCC TTI TGC TCA CCT GTG GT & & & GGG TGA ATG AGT AGG TGG & & \\
\hline $\begin{array}{l}\text { GCT GTC AAG CCG TGT TCT A } \\
\text { GTA TAA TTT ATA ACA ATA GTG CC }\end{array}$ & 5 & 132 & $\begin{array}{l}\text { CGG TGC TGG ACT TTG CG } \\
\text { AAG TGG ACA GTG AAG GCG }\end{array}$ & $\mathrm{F}$ & 186 \\
\hline $\begin{array}{l}\text { TTG GTT GTG CTG TGG CTC CT } \\
\text { ACA ATA CAT ACA AAC ATA GTG G }\end{array}$ & $14 \mathrm{~b}$ & 110 & $\begin{array}{l}\text { CCG TCT TGC GAG AGC ACC } \\
\text { CTA ATT TGC TGT GGG TTA GG }\end{array}$ & $\mathrm{H}^{*}$ & 262 \\
\hline $\begin{array}{l}\text { GAC TCT CCT TIT GGA TAC CTA } \\
\text { GCA TGA GCA TTA TAA GTA AGG }\end{array}$ & 12 & 90 & $\begin{array}{l}\text { AGT TGT GTA TAT TTG TGG TTA TG } \\
\text { GTT ACT GTG GAA AGG CAA TG }\end{array}$ & $J$ & 167 \\
\hline $\begin{array}{l}\text { GGC GAT GTT TIT TCT GGA GA } \\
\text { ACA AAT GAG ATC CTT ACC CC }\end{array}$ & 3 & 70 & $\begin{array}{l}\text { GAG ATC CCC TIT TCC AG } \\
\text { CAC AGC TGC CAG CAA TG }\end{array}$ & $\mathrm{N}^{*}$ & 176 \\
\hline $\begin{array}{l}\text { CFTR Exon } 21 \text { Primer Sequences } \\
\text { CAA GTG AAT CCT GAG CGT GAT TT } \\
\text { CAA AAG TAC CTG TTG CTC CA }\end{array}$ & $\begin{array}{l}\text { Name } \\
\text { SS\#1 }\end{array}$ & $\begin{array}{l}\text { Size (bp) } \\
\quad 477\end{array}$ & $\begin{array}{l}\text { CTC ACT GTG CCC ACA TTG } \\
\text { CAA ПTT CAT TCC ACA ATA G }\end{array}$ & $\mathrm{O}^{*}$ & 211 \\
\hline $\begin{array}{l}\text { GAA CTT GAT GGT AAG TAC ATG GGT G } \\
\text { AGT CAA AAG TAC CTG TTG CTC CAG }\end{array}$ & SS\#2 & 389 & $\begin{array}{l}\text { * Reported previously by Varanasi et al } \\
\text { "*Reported previously by Navon \& Proia } \\
\text { "* Reported previously by Tanaka et al }\end{array}$ & $\begin{array}{l}1994 . \\
1989 . \\
1990 .\end{array}$ & \\
\hline $\begin{array}{l}\text { TGA TGG TAA GTA CAT GGG TG } \\
\text { CAA AAG TAC CTG TTG CTC CA }\end{array}$ & SS\#3 & 381 & $\begin{array}{l}\text { NOTE: } \\
\text { Amplicon sizes increase by } 40 \mathrm{bp} \text { for chi }\end{array}$ & neric primers. & \\
\hline
\end{tabular}

high glucose ACD Vacutainers (Becton Dickinson Vacutainer Systems, Rutherford, NJ). Following centrifugation, the buffy coat was collected and lysed with two washes of a 10:1 ( $\mathrm{vol} / \mathrm{vol})$ solution of $14 \mathrm{mM} \mathrm{NH}_{4} \mathrm{Cl}$ and $1 \mathrm{~mm} \mathrm{NaHCO}_{3}$. The lymphocytes were harvested by centrifugation, resuspended in lysis buffer (10 mM Tris- $\mathrm{HCl}$ at $\mathrm{pH} 8.0,0.4 \mathrm{M} \mathrm{NaCl}, 2$
mM EDTA, $0.5 \%$ SDS, $500 \mu \mathrm{g} / \mathrm{ml}$ of proteinase $\mathrm{K}$ ) and incubated overnight at $37^{\circ} \mathrm{C}$. Samples were extracted with onefourth volume of saturated $\mathrm{NaCl}$, and the DNA was collected by ethanol precipitation. The DNA was washed with $70 \%$ ethanol, air-dried, and dissolved in TE (10 mm Tris- $\mathrm{HCl}$ at $\mathrm{pH} 7.5,1 \mathrm{~mm}$ EDTA).

Buccal cell samples were obtained by brushing the lining of the buccal cavity for 30 sec with a sterile cytology brush (Scientific Products no. S7766-1a). DNA was prepared by immersing the brushes in $600 \mu \mathrm{l}$ of $50 \mathrm{~mm} \mathrm{NaOH}$ in $1.2-\mathrm{ml} 96-$ well polypropylene tubes (USA/Scientific Plastics, Ocala, FL) and vortexed. The tubes, still containing the brushes, were heated to $95^{\circ} \mathrm{C}$ for $5 \mathrm{~min}$ and the 
SHUBER ET AL.
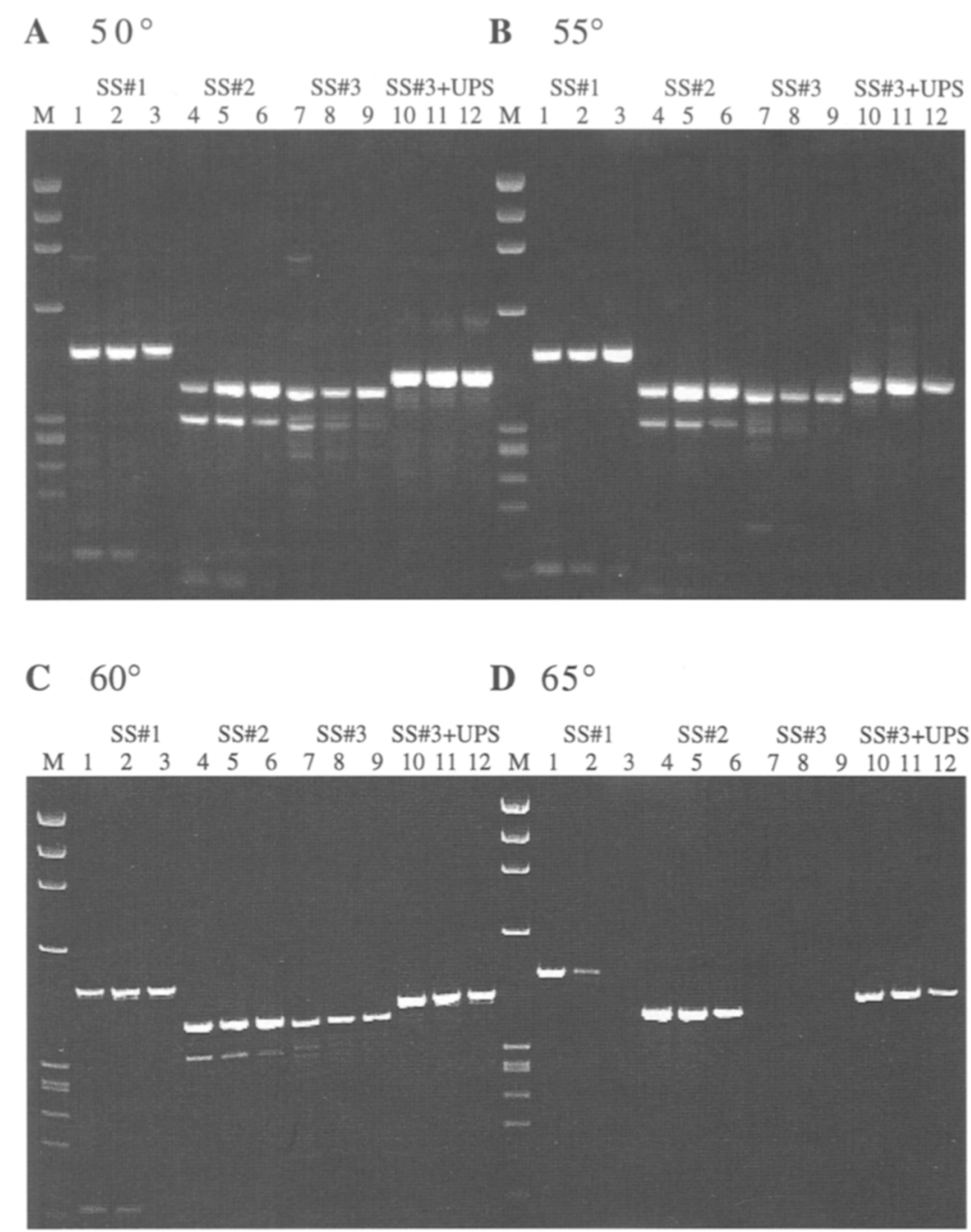

FIGURE 1 Gel electrophoretic analysis examining primer concentration and annealing temperature for PCR amplification of CFTR exon 21. Primers were serially diluted twofold for each primer pair (SS\#1, SS\#2, SS\#3, and SS\#3 + UPS; see Table 1). Primer pairs SS\#1, SS\#2, and SS 3 are sequence-specific primers only; SS\#3+UPS is chimeric with the $5^{\prime}$ UPS sequence. $(A)$ Annealing temperature of $50^{\circ} \mathrm{C} ;(B)$ annealing temperature of $55^{\circ} \mathrm{C} ;(C)$ annealing temperature of $60^{\circ} \mathrm{C} ;(D)$ annealing temperature of $65^{\circ} \mathrm{C}$. (Lanes $1,4,7,10$ ) Specified primers at $1.0 \mu \mathrm{M}$; (lanes $2,5,8,11$ ) specified primers at $0.5 \mu \mathrm{M}$; (lanes $3,6,9,12$ ) specified primers at $0.25 \mu \mathrm{M}$; (lane $\mathrm{M}$ ) $\phi X 174$ HaeIII-digested marker DNA.

brushes were removed carefully. The lysates were neutralized with $60 \mu \mathrm{l}$ of $1 \mathrm{M}$ Tris- $\mathrm{HCl}(\mathrm{pH} \mathrm{8.0)}$ and vortexed. Samples were stored at $4^{\circ} \mathrm{C}$. Sample aliquots of 10 $\mu l$ were used in a $100-\mu l$ PCR.

\section{Primer Design}

The sequences of the primer pairs and the predicted size of the corresponding amplification products are listed in Table 1. Sequence-specific primers were chosen without regard to hairpin formation and having a calculated $\Delta \mathrm{G}$ for primer duplexing below $-10 \mathrm{kcal} /$ mole.
The $T_{\mathrm{m}}$ of these primers ranges from $52^{\circ} \mathrm{C}$ to $68^{\circ} \mathrm{C}$ as determined by the $\mathrm{A}+\mathrm{T} / \mathrm{G}+\mathrm{C}$ method. To evaluate potential primer dimer formation within a primer set, primers sets were analyzed using Amplify 1.2 software (University of Wisconsin, Department of Genetics, Madison). Primers that have been reported previously in the literature are indicated in Table 1.

The universal primer sequence (UPS) 5'-GCGGTCCCAAAAGGGTCAGT-3' is from bacteriophage M13mp18. ${ }^{(8)}$ The UPS-tagged primers contain the 20-nucleotide UPS sequence attached to the $5^{\prime}$ end of the individual sequence-specific primers listed in Table 1. Oligonucleotide primers were synthesized by Operon Technologies (Alameda, CA). Oligonucleotides were HPLC purified and quantitated by spectrophotometry.

\section{Amplifications}

PCR amplifications were performed using $4 \mu \mathrm{l}(1-2 \mu \mathrm{g})$ and $10 \mu \mathrm{l}(5-50 \mathrm{ng})$ of genomic DNA prepared from either blood or buccal cells, respectively. PCR amplifications were done using a PerkinElmer 9600 Thermal Cycler (PerkinElmer, Norwalk, CT) for 28 cycles with ramping $\left(94^{\circ} \mathrm{C} / 10\right.$-sec hold with 48 -sec ramp, $60^{\circ} \mathrm{C} / 10$-sec hold with $36-\mathrm{sec}$ ramp, $72^{\circ} \mathrm{C} / 10$-sec hold with 38 -sec ramp). Reactions $(50 \mu \mathrm{l})$ were carried out in $1 \times$ PCR buffer $(10 \mathrm{~mm}$ Tris- $\mathrm{HCl}$ at $\mathrm{pH}$ $8.3,50 \mathrm{~mm} \mathrm{KCl}, 1.5 \mathrm{mM} \mathrm{MgCl}_{2}$ ), $200 \mu \mathrm{M}$ dNTPs, 2.5 units of $T a q$ polymerase (Perkin-Elmer, Norwalk, CT). Multiplex PCR reactions were performed in a volume of $100 \mu \mathrm{l}$ under the same conditions except that 10 units of Taq polymerase per reaction was used. Primer concentrations are given in the figure legends.

For PCR product analyses, $8 \mu \mathrm{l}$ of the amplification reactions was loaded directly onto a $2 \%$ ethidium bromidestained agarose gel and electrophoresed at $250 \mathrm{~V}$ for $90 \mathrm{~min}$. The amplification products were visualized with a UV transilluminator (Fotodyne, New Berlin, WI) and photographed with an Alpha Innotech IS-500 Digital Imaging System version 1.97 (Sun Bioscience Inc., Branford, CT).

\section{RESULTS}

To evaluate the use of tagged primers for multiplex PCR, the 32 primer pairs presented in Table 1 were employed either alone or as chimeric primers containing a 20-nucleotide tag (GCGGTCCCAAAAGGGTCAGT) corresponding to the M13mp18 UPS at the $5^{\prime}$ end. The $T_{\mathrm{m}}$ for all of the chimeric primers was calculated to be $>72^{\circ} \mathrm{C}$.

Using standard PCR components (see Materials and Methods), oligonucleotide concentrations and cycling parameters were evaluated for individual primer pairs. Figure 1 represents the amplification results comparing three sequence-specific primer pairs, which amplify exon 21 of the cystic fibrosis (CF) 


\section{SIMPLIFIED METHOD FOR MULTIPLEX PCR DEVEOPMENI}

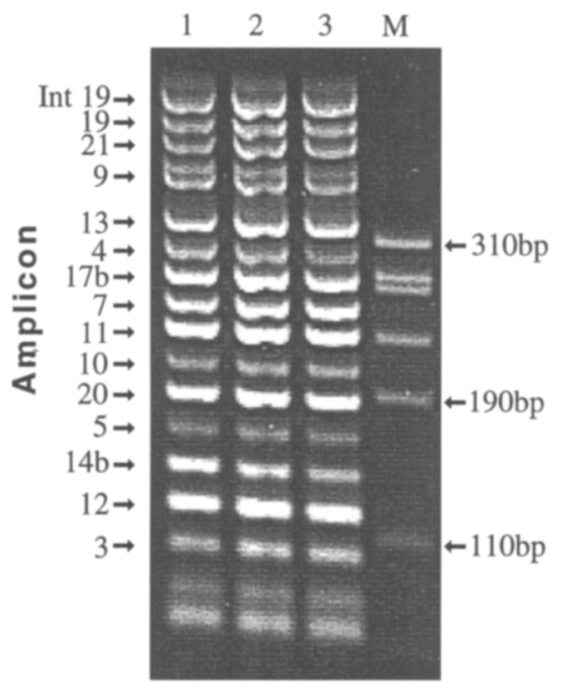

FIGURE 2 CFTR 15-plex amplicon organization. (Lanes 1-3) Multiplex amplification of three different genomic DNA samples isolated from blood. All samples were amplified with CFTR chimeric 15-plex primers (See Table 1) at the following primer pair concentrations: Int 19, $0.5 \mu \mathrm{M}$; exon 19, $0.5 \mu \mathrm{M}$; exon 21, $1.0 \mu \mathrm{M}$; exon 9, $0.75 \mu \mathrm{M}$; exon $13,1.0 \mu \mathrm{M}$; exon $4,1.0 \mu \mathrm{M}$; exon $17 \mathrm{~b}, 0.5 \mu \mathrm{M}$; exon $7,0.5$ $\mu \mathrm{M}$; exon 11, $1.0 \mu \mathrm{M}$; exon 10, $1.0 \mu \mathrm{M}$; exon 20, $0.25 \mu \mathrm{m}$; exon 5, $0.5 \mu \mathrm{m}$; exon $14 \mathrm{~b}, 0.5 \mu \mathrm{M}$; exon $12,0.5 \mu \mathrm{M}$; exon $3,0.25 \mu \mathrm{M}$. (Lane $\mathrm{M}$ ) $\phi X 174$ HaelII-digested marker DNA.

gene, ${ }^{(9)}$ with a primer pair tagged with the UPS sequence. The results show that the addition of the UPS tag confers enhanced specificity over a fourfold range of primer concentrations while retaining amplification efficiency at annealing temperatures from $50^{\circ} \mathrm{C}$ to $65^{\circ} \mathrm{C}$. Based on this and similar analyses of additional chimeric primer pairs, an annealing temperature of $60^{\circ} \mathrm{C}$ was determined to be optimal for PCR amplification using UPS-tagged primers.

To assess the use of chimeric primers for multiplex PCR, a system was designed using 15 UPS-tagged primer pairs specific for the CF transmembrane conductance regulator locus (CFTR). An example of the gel electrophoretic pattern of the multiplex PCR products is shown in Figure 2. As demonstrated for exon 21 (Fig. 1), each chimeric primer pair concentration used within the CFTR 15-plex was determined by performing independent amplicon amplifications over a range of concentrations (Fig. 2). Using the same amplification conditions that were originally defined for the individual chimeric primer pairs, all 15 of the predicted CFTR PCR products coamplified with relative ease. It should be emphasized that the CFTR multiplex reactions presented in Figure 2 and all subsequent reactions employed the same reaction components, cycling times, and temperatures without modification from the single amplicon assay conditions. The only optimization required was an adjustment of the primer concentrations for intron 19 and exon 19 to generate comparable band intensities of the coamplified products.

To demonstrate the enhanced specificity and efficiency conferred by the UPS sequence in multiplex PCR, parallel reactions were carried out using UPStagged CFTR primers and the corresponding nontagged primers. Identical reaction conditions, cycling times, and primer concentrations were used for both primer sets. Previously, optimal primer concentrations were determined for the individual primer pairs. Coincidentally, the optimal concentrations determined in this manner were identical for both the UPS- and non-UPS-tagged primers. As shown in Figure 3, the multiplex amplification using the standard sequence-specific primer pairs failed to generate a clear multiplex PCR profile of the CFTR locus. Specifically, several of the expected bands were clearly underrepresented, presumably owing to differential PCR amplification of their respective products (Fig. 3, lanes 5-8, 13-16). In contrast, a clear multiplex profile was obtained when the CFTR locus was amplified with the corresponding UPStagged primer pairs. The expected bands were clearly prominent and virtually free of contaminating products (Fig. 3, lanes 1-4, 9-12). Moreover, equivalent banding patterns were observed over an eightfold range of template concentrations when the UPS-tagged primer pairs were employed. Conversely, the amplification profile generated using sequence-specific primers was sensitive to variations in the template concentration as evident by the changes in the intensity of individual bands (Fig. 3, lanes $5-8,13-16)$.

To further demonstrate the general utility of the UPS-tagged primers, 29 different human genomic target sequences (Table 1 ) were amplified in a single thermal cycler under identical reaction conditions and cycling parameters. Results from these amplification reactions using sequence-specific primer pairs and the cognate UPS-tagged primer pairs are presented in Figure 4. By using the tagged primers, predicted amplification products were generated from 28 of the 29 primer pairs studied.

The banding patterns observed represent multiplex or single amplicon amplifications of sequences associated with $C F,{ }^{(9)}$ Gaucher disease, ${ }^{(10)}$ Sickle cell anemia, ${ }^{(3)}$ Tay-Sachs, ${ }^{(11,12)} \beta$-thalassemia, ${ }^{(13)}$ and Wilms tumor. ${ }^{(14)}$ Results from the multiplex PCR reactions demonstrate that for both single gene mul-

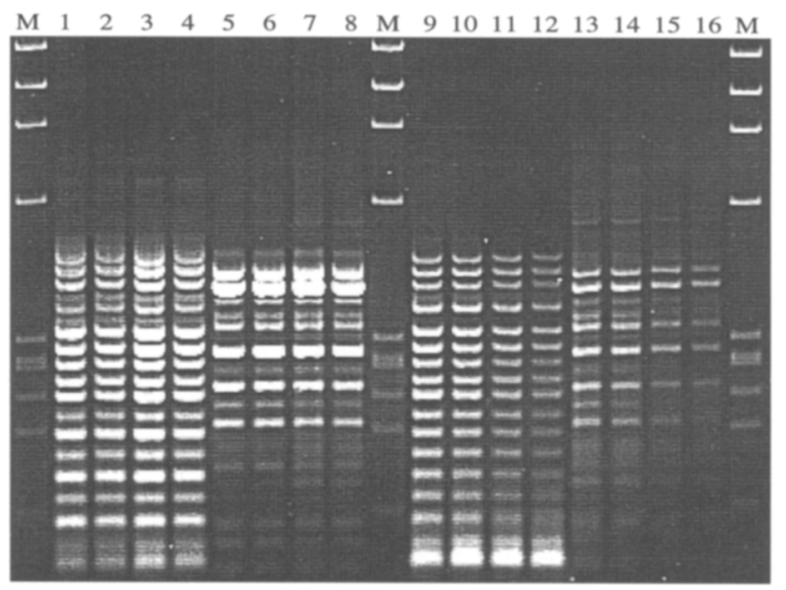

FIGURE 3 Comparison of chimeric primers with sequence-specific primers for CFTR 15-plex PCR amplification. (Lanes 1-8) Genomic DNA samples isolated from blood; (lanes 9-16) genomic DNA samples isolated from buccal cells. Each consecutive sample in the group of four amplifications represents a twofold serial dilution of genomic DNA. (Lanes 1-4, 9-12) CFTR 15-plex amplification with chimeric primers; (lanes 5-8, 13-16) CFTR 15-plex amplification with sequence-specific primers; (lane M) $\phi$ X174 HaellI-digested marker DNA. 

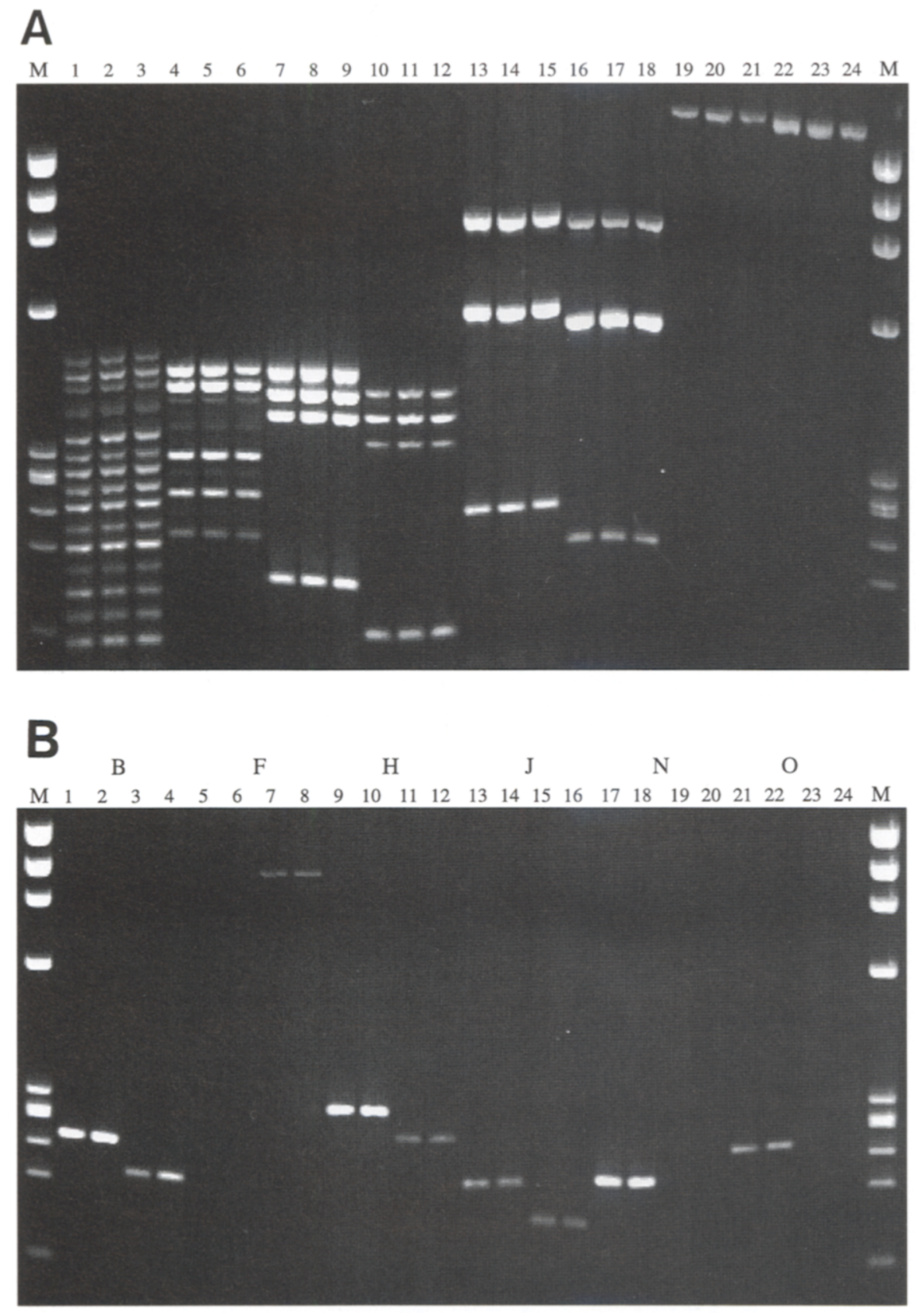

FIGURE 4 Results from multiple gene loci amplifications performed in a single PCR thermal cycler under identical reaction conditions and cycling parameters. $(A)$ (Lanes 1-3) Amplification of CFTR 15-plex with chimeric primers; (lanes 4-6) amplification of CFTR 15-plex with sequence specific primers; (lanes 7-9) multiplex amplification of GCR 3-plex and single SCA target with chimeric primers; (lanes 10-12) multiplex amplification of GCR 3-plex and single SCA target with sequence specific primers; (lanes 13-15) multiplex amplification of single GCR target and TS 2-plex with chimeric primers; (lanes 16-18) multiplex amplification of single GCR target and TS 2-plex with sequence specific primers; (lanes 19-21) amplification of single $\beta$-thalassemia target with chimeric primers; (lanes 22-24) amplification of single $\beta$-thalassemia target with sequence-specific primers. All primer pairs were tested on three different genomic DNA samples isolated from blood. (Lane M) $\phi X 174$ Haelli-digested marker DNA. (B) Independent amplification of six target sequences within the Wilms' tumor gene. (Lanes 1,2,5,6,9,10,13,14,17,18, 21,22 ) amplifications performed with chimeric primers; (lanes $3,4,7,8,11,12,15,16,19,20,23,24$ ) amplifications performed with sequence specific primers. All primer pairs tested on two independent genomic DNA samples isolated from blood; (lane M) $\phi$ X174 HaellI-digested marker DNA. tiplexes (Fig. 4A, lanes 1-3) and multiplex reactions involving more than one gene (Fig. 4A, lanes 7-9, 13-15), the UPS-tagged primers generated only the desired bands, and the co-amplified products were more uniform with respect to the band intensities than the corresponding products generated from the non-tagged sequence-specific primers (Fig. 4A, lanes 4-6, 10-12, 16-18). Amplification of six different regions within the Wilms' tumor gene is presented in Figure $4 \mathrm{~B}$. With the exception of one primer pair (Fig. 4B, lanes 5-8), which did not generate a detectable product when the chimeric primer was employed, the presence of the UPS sequence enhanced the yield of the respective PCR products (Fig. 4B, lanes $1-4,9-12,13-16,17-20,21-24)$.

\section{DISCUSSION}

We have developed an amplification system for multiplex PCR that is based on the use of chimeric primers tagged on the $5^{\prime}$ end with an unrelated 20-nucleotide sequence (UPS). Our results demonstrate that multiple genomic sequences can be coamplified under identical reaction conditions and cycling parameters with very little optimization of PCR conditions. Highly specific and efficient amplification of target sequences can be achieved easily and reproducibly by simple adjustment of the individual primer concentrations, with no additional modification of either the reaction components or annealing temperatures.

Furthermore, for each of the multiplex systems studied, comparable yields of the individual coamplified products were obtained when the UPS-tagged primers were employed (Fig. 4A). The most significant effect of UPS-tagged primers is seen when developing very complex multiplex PCRs. As demonstrated with the development of the CFTR 15-plex, in reactions using the UPS-tagged primers, amplicon banding patterns were consistent between experiments and over a range of template DNA concentrations. The UPS-tagged primers produced clean visibly detectable PCR profiles over an eightfold range of template DNA concentrations (Fig. 3). In contrast, several of the corresponding products amplified using the nontagged primer pairs were either weak or undetectable (Fig. 3 and Fig. 4A, lanes 4-6). Moreover, the high level of consistency, 


\section{SIMPLIFIED METHOD FOR MULTIPLEX PCR DEVEOPMENT}

with respect to the relative band intensities, increases the informativeness and simplifies the interpretation of the results. In addition to the development of multiplex PCRs, we have demonstrated the general utility of the UPS-tagged primers. For all genomic amplifications, a single thermal cycler program can be used because the reaction conditions and cycling parameters are identical for all UPS-tagged primers.

We believe the enhanced specificity and efficiency that is conferred by the tagged primers is attributable to a normalization of the hybridization kinetics. During the early rounds of the PCR, molecules are synthesized that contain the tagged primers at their $5^{\prime}$ ends. Therefore, in all subsequent rounds of amplification, the amplicons synthesized will all have identical 20-bp priming sequences with the predicted hybridization kinetics of the UPS tag. A significant concern with this approach is the possible production of spurious products owing to nonspecific annealing of the chimeric primers during the first few PCR cycles. However, by having an extremely GC-rich region at the $5^{\prime}$ end of the UPS sequence, we believe that under PCR conditions optimal for the UPS tag, nucleation is progressing in a primer-oriented $5^{\prime} \rightarrow 3^{\prime}$ direction. In addition, each chimeric primer pair has a 3 ' sequence-specific region with an internal stability profile $(\Delta G)$ for primer duplexing lower than the UPS tag. Therefore, chimeric primers, which have an overall $T_{\mathrm{m}}$ significantly $>72^{\circ} \mathrm{C}$ serve as highly efficient yet stringent recognition sequences for the subsequent rounds of the PCR. By normalizing the hybridization kinetics, we have largely eliminated the need to evaluate diverse reaction conditions and cycling parameters. Therefore, the use of UPS-tagged primers provides a less costly method in terms of polymerase, labor, and time and should greatly simplify the development of complex multiplex PCRs to be used in new diagnostic tests. Although we have developed this technique for the application to human disease genes, it should be equally applicable to multiplex mapping projects and to infectious diseases designed to detect multiple pathogens.

\section{ACKNOWLEDGMENTS}

We thank Dr. Lesley Michalowsky for editorial advice and all of the members in the Technology Development group for their technical support and advice.

The publication costs of this article were defrayed in part by payment of page charges. This article must therefore be hereby marked "advertisement" in accordance with 18 USC section 1734 solely to indicate this fact.

\section{REFERENCES}

1. Maxam, A.M. and W. Gilbert. 1980. Sequencing end-labeled DNA with basespecific chemical cleavages. Methods Enzymol. 65: 499-560.

2. Sanger, F., S. Nicklen, and A.R. Coulson. 1977. DNA sequencing with chain terminating inhibitors. Proc. Natl. Acad. Sci. 74: 5463-5467.

3. Saiki, R.K., T.L. Bugawan, G.T. Horn, K.B. Mullis, and H.A. Erlich. 1986. Analysis of enzymatically amplified beta-globin and HLA-DQ alpha DNA with allele-specific oligonucleotide probes. Nature 324: $163-$ 166.

4. Landegren, U., R. Kaiser, J. Sanders, and L. Hood. 1988. A ligase-mediated gene detection technique. Science 241: 10771080.

5. Orita, M., H. Iwahana, K. Hayashi, and T. Sekiya. 1989. Detection of polymorphisms of human DNA by gel electrophoresis as single-strand conformational polymorphisms. Proc. Natl. Acad. Sci. 86: $2766-2770$.

6. Chamberlain, J.S., R.A. Gibbs, J.E. Ranier, P.N. Nguyen, and C.T. Caskey. 1988. Deletion screening of the Duchenne muscular dystrophy locus via multiplex DNA amplification. Nucleic Acids Res. 16: $11141-11156$.

7. Edwards, M.C. and R.A. Gibbs. 1994. Multiplex PCR: Advantages, development, and applications. PCR Methods Applic. 3: S65-S75.

8. Messing, J. 1983. New M13 Vectors for Cloning. Methods Enzymol. 101: 20-78.

9. Kerem, B., J.M. Rommens, J.A. Buchanan, D. Markiewicz, T.K. Cox, A. Chakravarti, M. Buchwald, and L.-C. Tsui. 1989. Identification of the cystic fibrosis gene: Genetic analysis. Science 245: 1073-1080.

10. Beutler, E. 1992. Gaucher disease: New molecular approaches to diagnosis and treatment. Science 256: 794-799.

11. Navon, R. and R.L. Proia. 1989. The mutations in Ashkenazi Jews and adult $\mathrm{G}_{\mathrm{M} 2}$ gangliosidosis, the adult form of TaySachs disease. Science 243: 1471-1474.

12. Tanaka, A., K. Ohno, K. Sandhoff, I. Maire, E.H. Kolodny, A. Brown, and K. Suzuki. 1990. $\mathrm{G}_{\mathrm{M} 2}$-Gangliosidosis B1 Variant: Analysis of beta-hexosaminidase alpha gene abnormalities in seven pa- tients. Am. J. Hum. Genet. 46: 329-339.

13. Kazazian, H.H. Jr. and C.D. Boehm. 1988. Molecular basis and prenatal diagnosis of beta-thalassemia. Blood 72: 1107-1116.

14. Varanasi R., N. Bardeesy, M. Ghahremani, M.J. Petruzzi, N. Nowak, M. Adam, P. Grundy, T.B. Shows, and J. Pelletier. 1994. Fine structure analysis of the WT1 gene in sporadic Wilms tumors. Proc. Natl. Acad. Sci. 91: 3554-3558.

Received August 1, 1995; accepted in revised form November 17, 1995. 


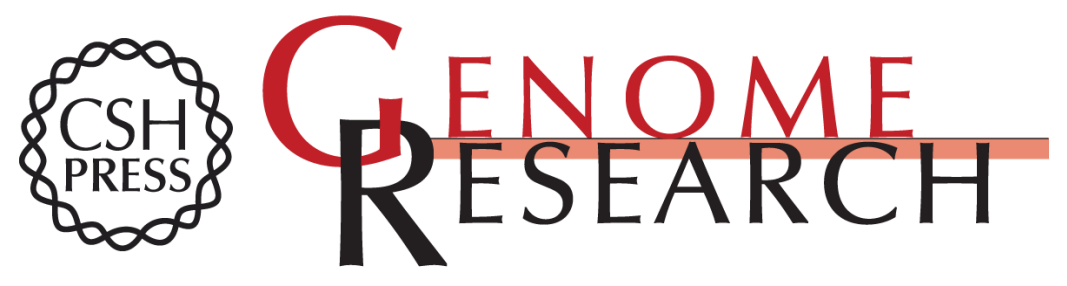

\section{A simplified procedure for developing multiplex PCRs.}

A P Shuber, V J Grondin and K W Klinger

Genome Res. 1995 5: 488-493

Access the most recent version at doi:10.1101/gr.5.5.488

References This article cites 14 articles, 8 of which can be accessed free at:

http://genome.cshlp.org/content/5/5/488.full.html\#ref-list-1

\section{License}

Email Alerting Receive free email alerts when new articles cite this article - sign up in the box at the Service top right corner of the article or click here.

\section{Affordable, Accurate Sequencing.}

To subscribe to Genome Research go to: https://genome.cshlp.org/subscriptions 